\title{
O Proteu do abuso sob os olhos do Parlamento: verdade dos orçamentos e prestação de contas no Império do Brasil*
}

\author{
The Proteus of abuse under Parliament's eyes: truth of State \\ budgeting and accountability in the Empire of Brazil
}

\author{
Adelino Martins $\star \star$
}

Resumo: Este texto propõe-se a explicar por que, no Império do Brasil, não foi criado um tribunal de contas e não foram codificadas as leis de contabilidade pública, embora tais matérias tenham sido discutidas no Parlamento desde 1826. O problema foi tratado no bojo das discussões sobre a verdade dos orçamentos e a fiscalização das contas públicas, assuntos que remetiam aos diferentes pontos de vista de Luzias e Saquaremas quanto à divisão de poderes na monarquia. As reformas das instituições de contabilidade pública e tomada de contas efetuadas no Império foram analisadas à luz dos debates parlamentares e da bibliografia de apoio. A abordagem foi institucionalista histórica e as fontes investigadas foram os relatórios dos ministros da Fazenda, os anais da Câmara dos Deputados e do Senado, jornais e livros de época.

Palavras-chave: Verdade dos orçamentos. Contabilidade pública. Projetos de tribunais de contas. Checks and balances. Prestação de contas no Império do Brasil.

Abstract: This text aims to explain why, during the Empire of Brazil, a court of accounts was not created and the laws of public accounting were not codified, although such matters have been discussed in the Parliament since 1826. The subject was addressed considering the discussions on the truth of State budgeting and the supervision of public accounts, which referred to Luzias's and Saquaremas's points of view regarding the separation of powers in the Empire. We analysed the reforms in the public accounting and accountability institutions in the light of parliamentary debates and the supporting bibliography. The approach was historical institutionalist. Our sources were the reports of the Ministers of Finance, records of the House of Representatives and the Senate, newspapers and books of the time.

Keywords: Truth of State budgeting. Public accounting. Projects of courts of accounts. Checks and balances. Accountability in the Empire of Brazil.

JEL: H60. H83. N46.

\footnotetext{
* Submissão: 21/07/2020 | Aprovação: 27/06/2021 | DOI: 10.29182/hehe.v24i3.760

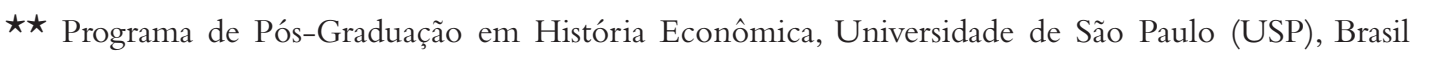
ORCID: 0000-0002-2076-7132 | E-mail:mart7ins@gmail.com
} 


\section{Introdução}

O controle externo das contas da administração pública e a codificação das normas de contabilidade do setor público foram, no Brasil, construções institucionais da República. O Tribunal de Contas da União foi criado em 1890 e o Código de Contabilidade, em 1922. Entretanto, a instituição de uma organização independente com relação ao Poder Executivo, com a função de auxiliar a fiscalização parlamentar das contas públicas, e a sistematização das normas que presidiam a elaboração dos orçamentos e dos balanços foram medidas debatidas durante o período imperial. Elas eram entendidas como complementares por seus defensores; necessárias para que o Parlamento pudesse aferir a verdade dos orçamentos. Todavia, não foram efetivadas no Império.

Rui Barbosa, o primeiro ministro da Fazenda da República, na exposição de motivos do projeto que culminou com a criação do Tribunal de Contas da União, atacou o legado imperial: "onde a responsabilidade ministerial contra os abusos orçamentários no regimen passado durante quase três quartos de século de monarquia constitucional?” (Brasil, 1890, p. 3.436). Para ele, o sistema de contabilidade vindo do Império era defeituoso, pois não permitia resguardar a inviolabilidade do orçamento.

$\mathrm{O}$ incômodo com o sistema de contabilidade pública foi externado durante o Império na Câmara dos Deputados e no Senado, essencialmente pelos liberais. Na imprensa, o Jornal do Commercio (1883b) ecoou o descontentamento. Em janeiro de 1883, criticou a intrincada distribuição de créditos orçamentários. Em 27 de julho do mesmo ano, afirmou que os balanços imperiais, confusos, eram como o Proteu da mitologia grega, que se disfarçava para negar informações aos parlamentares que o interpelavam (Jornal do Commercio, 1883a).

Este artigo discute as razões pelas quais o regime imperial não criou uma instituição de controle externo e não codificou as normas de contabilidade pública. Trata-se de assunto pouco visitado pela historiografia e que, aqui, é tratado em quatro períodos: 1826 a 1832, quando se discute o primeiro projeto para a criação de um tribunal de revisão de contas e se regulamenta o funcionamento do Tesouro Nacional; 1837 a 1845, intervalo que comportou o fracasso de dois projetos para criar uma corte de contas; 1850 a 1873, fase de consolidação das reformas saquaremas do sistema de contabilidade pública e julgamento de contas; e os anos finais do Império, quando demandas por reformas do sistema de contabilidade pública e pela criação 
de um tribunal de contas apareceram com frequência nos relatórios dos ministros da Fazenda.

\section{Breve discussão historiográfica}

Não são numerosos os estudos que tratam da história do controle externo da administração pública e da contabilidade do setor público no Império do Brasil. Na segunda década do século XX,Viçoso Jardim (1917) ofereceu um escorço histórico sobre os assuntos, com informações pormenorizadas quanto ao período imperial, que visavam a explicar as origens das instituições públicas contábeis e de tomada de contas de seu tempo. Murilo de Carvalho (2010) discutiu os conflitos de interesse acerca da repartição de recursos orçamentários, mas não as disputas sobre como deveria ser julgada a aderência da execução orçamentária às autorizações votadas pelo Parlamento e aos termos da legislação aplicável, o que, à época, comumente, chamava-se de verdade dos orçamentos. Silva (2005) inventariou as normas legais e infralegais atinentes à contabilidade pública veiculadas pelo Império, sem, contudo, relacioná-las ao debate político sobre a fiscalização das contas públicas. Rodrigues et al. (2015) discorreram sobre os procedimentos contábeis efetuados para registrar as operações do comércio de escravos e o imposto da meia siza.

O orçamento do Império foi objeto de estudo ainda nos anos 1850 pelo conde belga Straten-Ponthoz (1854), que considerava o orçamento um mirante privilegiado para avaliar o funcionamento das instituições dos governos representativos, embora não tenha aprofundado a discussão sobre a fiscalização parlamentar da execução orçamentária. Esse, no entanto, era um ponto conflituoso, em particular no que dizia respeito às receitas tributárias, já que os estados eram acusados de avançar sobre competências centrais. Deveza (2016) tratou da carência de efetiva fiscalização sobre esse aspecto. Ramos (2018) atentou que a separação das receitas gerais e provinciais foi propositalmente mal definida nos anos 1830 e seguiu não resolvida ao longo do Império. Lopes e Hanley (2014) mostraram que os municípios, por seu turno, sofreram com a falta de regulamentação orçamentária e que os seus balanços não eram elaborados com base nas prestações de contas dos anos anteriores.

A própria ideia de prestação de contas foi foco de discussões no Império. Aidar (2016) mostrou como a proposta de criação de um tribunal de contas para exame das contas ministeriais em auxílio ao Parlamento foi preterida nas discussões que culminaram com a reforma do Tesouro de 1831. Com 
efeito, de 1826 até o final do Império, a questão da modelação institucional da prestação de contas das execuções orçamentárias apareceu nos debates entre os ministros da Fazenda e os parlamentares, inserida nos marcos mais amplos das divergências sobre a repartição de poderes na monarquia brasileira.A conformação das instituições de controle orçamentário e contábil no Império resultou da vitória de uma visão sobre o papel delas no sistema constitucional do regime. Este texto revisita esse processo de construção.

\section{Conceitos empregados e método de análise}

Este artigo pretende explicar por que, apesar de discutidas ao longo do período imperial, a criação de um tribunal de contas e a sistematização das normas de contabilidade pública não foram realizadas. Parte-se, pois, de um problema, expediente de pesquisa que, como notou D'Assunção Barros (2013), tornou-se frequente entre os historiadores depois da influência dos Annales. ${ }^{1}$ A abordagem é institucionalista histórica.

North (2003) definiu as instituições, formais e informais, como as regras do jogo em uma sociedade, criadas para influenciar as interações humanas. Hall e Taylor (2003) enfatizaram que os estudos institucionalistas históricos associam as instituições a procedimentos, protocolos, normas e convenções inerentes à estrutura das comunidades políticas e da economia. O presente trabalho tratou de instituições formais, das organizações e das regras legalmente definidas para a contabilidade pública e a tomada de contas da administração pública.

As regras e organizações atinentes à contabilidade pública e à prestação de contas foram analisadas nos marcos das discussões entre liberais e conservadores sobre a repartição de poderes na monarquia constitucional. Seus discursos foram comparados com os resultados institucionais, vale dizer, com as normas positivadas para dispor sobre a tomada de contas e os controles contábeis, a fim de se avaliar quais perspectivas tornaram-se políticas de Estado.

As fontes investigadas para realizar o trabalho foram os relatórios de ministros da Fazenda e de presidentes do Conselho de Ministros; repositórios legais; anais parlamentares; livros e jornais de época. A análise foi qualitativa e as informações colhidas foram interpretadas à luz da bibliografia referenciada. Para abordar o problema que o texto propôs elucidar, recorreu-se,

\footnotetext{
${ }^{1}$ Sobre isso, ver o manifesto dos novos Annales (Febvre, 1989).
} 
sobretudo, à noção de controle administrativo das contas sistematizada pelo Visconde do Uruguai (1862) e ao conceito elaborado por Mattos (1987) de direção política e intelectual saquarema.

\section{Resultados}

\subsection{Um sistema monstruoso (1826-1832)}

Em 1826, o senador Felisberto Caldeira Brandt, então Visconde de Barbacena, caracterizou o sistema de administração fazendária do recém-independente país como monstruoso. Corria o primeiro ano da primeira legislatura do Parlamento e ele, em coautoria com o senador José Ignácio Borges, propôs um projeto para regulamentar o artigo 131 da Constituição do Império, que remetia à lei a definição do número de secretarias de Estado e as suas competências. Eles inseriram no artigo 10 do projeto a criação de um tribunal de revisão de contas. No plenário do Senado, Barbacena antecipou o princípio geral que norteava a proposta: “existimos n'um governo monárquico constitucional, convinha, pois, que não seguíssemos as mesmas formas de um governo absoluto" (Brasil, 1878c, p. 122).

$\mathrm{Na}$ discussão do projeto, Barbacena explicitou o que entendia por "não seguir as formas do governo absoluto":

Nada há mais monstruoso, do que o actual systema de administração da fazenda. É um só ministro quem tem tudo a seu cargo: elle arrecada todas as rendas da nação, elle manda pagar todas as despezas, e depois elle mesmo no princípio do anno julga das suas contas do anno antecedente, e diz que estão na devida ordem. (Brasil, 1878d, p. 43)

O marco do sistema de administração criticado pelo senador foi o Alvará de 28 de junho de 1808. Ele criou o Erário Régio ou Tesouro Real e Público no Estado do Brasil, com as mesmas prerrogativas do Real Erário de Lisboa, definidas na Carta de Lei de dezembro de 1761. Independente o Brasil, a Constituição Imperial de 1824, em seu artigo 170, reservou ao Tesouro Nacional as incumbências que o Alvará de 1808 atribuíra ao Erário Régio. Elas incluíam a escrituração contábil por partidas dobradas e a avaliação das contas gerais da Fazenda, que, ao final de cada ano, deveriam subir à real presença. Barbacena julgava inadequado à monarquia constitucional o acúmulo das atribuições de execução e julgamento de contas. 
O contexto da proposição de Borges e Barbacena era o de oposição liberal a D. Pedro I no Parlamento, implacável segundoViotti da Costa (2007). A primeira legislatura imperial tinha à sua frente a tarefa de editar normas regulamentares sem as quais uma série de dispositivos constitucionais permaneceria com eficácia limitada. O ponto de partida dos debates iniciais, em 1826, foi a regulamentação do artigo 133 da Constituição de 1824, que dispunha sobre os crimes de responsabilidade dos ministros de Estado (Vellozo, 2017). A proposta de criação de um tribunal de revisão de contas foi o expediente de que se valeram Borges e Barbacena para inserir um dispositivo adicional de responsabilização ministerial no bojo da regulamentação de outro artigo constitucional, o 131.

O Poder Executivo, cônscio desse expediente, combateu o artigo 10 do projeto. Na sessão mesma do Senado em que houve a apresentação da proposta de Borges e Barbacena, o Visconde de Maricá asseverou que era injusto afirmar que as repartições não "davam suas contas" e que era inviável apreciar o projeto, porque não estava acompanhado do regulamento do tribunal que se pretendia criar. No dia seguinte, o ministro do Império e dos Estrangeiros, Visconde de Inhambupe, e o da Fazenda, o Visconde de Baependi, ambos senadores, atacaram o projeto por não apresentar o regulamento do tribunal e, sobretudo no caso de Baependi, por desconsiderar a fiscalização hierárquica que o ministro da Fazenda exercia sobre o tesoureiro-mor, responsável pela entrada e saída de dinheiros no Tesouro.

Indignado, o ministro da Fazenda defendeu o sistema fazendário alicerçado no Alvará de 1808 e afirmou que um tribunal de contas somente teria serventia caso avaliasse previamente as despesas. Se, como o projeto indicava, sua destinação era o julgamento de dispêndios já efetuados, concorreria apenas para o aumento dos gastos, pois não serviria sequer para apanhar corruptos. "Qual será o ladrão-mestre, e sagaz que se descubra pelo exame da liquidação das contas?" (Brasil, 1878d, p. 45), indagou retoricamente o ministro da Fazenda.

A intervenção de Baependi permite vislumbrar, a partir do papel da prestação de contas, duas diferentes visões sobre a separação dos poderes no governo constitucional que a Constituição de 1824 instituíra. Para o ministro da Fazenda, a supervisão hierárquica, ao âmbito do Poder Executivo, bastava. A posição é consentânea com a defesa que, anos depois, Uruguai (1862), notório conservador, faria da circunscrição da tomada de contas em âmbito administrativo, sob a jurisdição do Poder Executivo. Barbacena, por outro lado, apontava para um discurso comum entre os liberais anos depois: 
fortalecer o poder do Parlamento e limitar a ação governativa do imperador, valendo-se, entre outros mecanismos, de um tribunal de contas que tomasse contas e oferecesse subsídios ao Legislativo para efetuar a responsabilização ministerial.

Ao final da discussão do projeto de Barbacena, o artigo referente ao tribunal foi separado do restante do texto e teve sua discussão adiada. De fato, a ideia não prosperou no Primeiro Reinado. Com o advento da Regência, a organização do Tesouro foi dada pela lei de 4 de outubro de 1831, que consagrou o princípio da supervisão hierárquica defendida por Baependi. Curiosamente, o projeto que resultou na lei foi submetido à Câmara dos Deputados por Barbacena em 1830, quando ministro da Fazenda.

A justificativa para a mudança de opinião foi dada pelo ministro no plenário da Câmara:

O ministro da Fazenda não deve ser presidente do thesouro, segundo as minhas ideias, deve ser perfeitamente separado da administração do thesouro; e o tribunal de revisão de contas deve ser independente do ministro, porque tem a examinar todas as contas [...], mas enquanto a machina não está montada parece-me de incalculável vantagem reunir na mesma pessoa o presidente ou o administrador do thesouro e o ministro da fazenda [...] Poderia dizer-se que seria melhor fazer primeiro a creação de um tribunal de revisão de contas; mas eu entendo que não, por ora. (Brasil, 1878a, p. 396)

$\mathrm{O}$ artigo $1^{\circ}$ do projeto instituía o Tesouro Público Nacional, na forma de um tribunal. $\mathrm{O}$ artigo $8^{\circ}$ estabelecia as atribuições do órgão, que recobriam da direção à supervisão das receitas e despesas públicas, passando pela contabilização e a tomada de contas, ambas a cargo de uma contadoria especializada. $\mathrm{O}$ artigo $9^{\circ}$ definiu que o ministro da Fazenda seria o presidente nato do tribunal. Em suma, positivava-se a forma hierárquica de controle das contas públicas, defendida por Baependi quando da discussão da proposta efetuada pelos senadores Borges e Barbacena quatro anos antes. A justificativa dada pelo ministro da Fazenda foi a de um recuo estratégico. O projeto que enviara almejava, pois, organizar os serviços existentes antes de propor inovações institucionais. Ele foi analisado na Câmara dos Deputados e, ali, combatido por Bernardo Pereira de Vasconcelos, então destacado opositor liberal do imperador.

O deputado mineiro, que desde a primeira legislatura notabilizara-se 
por defender mecanismos de responsabilização de agentes públicos em geral e dos ministros de Estado em particular, ${ }^{2}$ insurgiu-se contra a Contadoria Geral de Revisão. Considerou-a inútil, pois "como póde a contadoria nomeada pelo governo tomar contas ao mesmo governo?” (Brasil, 1878a, p. 428). Vasconcelos teve que lidar com a pergunta um ano depois. A lei finalmente aprovada em 4 de outubro de 1831 manteve a combatida Contadoria Geral de Revisão e foi assinada pelo ministro da Fazenda de então, o próprioVasconcelos. Um ato do qual ele, depois de deixar as hostes liberais, não teve por que se envergonhar. Os membros do seu Partido Conservador, ao longo do Segundo Reinado, sustentariam essa forma de controle das contas públicas.

Antes de cerrar fileiras com o regresso, no entanto, Vasconcelos teve a oportunidade de administrar o sistema fazendário que tão acerbamente criticou. Ministro da Fazenda entre julho de 1831 e maio de 1832, eximiu-se, no relatório dirigido ao Parlamento, de responder à pergunta que opusera a Barbacena em 1830. Noticiou que a lei "novíssima" havia reorganizado o Tesouro e não perdeu a oportunidade de criticar a Contadoria de Revisão de Contas, que haveria de "conservar-se inactiva, e inutil" (Brasil, 1832, p. 38) até a organização das tesourarias provinciais.

Tal estado de coisas contrariava as convicções que Vasconcelos afirmava esposar. Para ele, o mais importante da administração da Fazenda consistia na revisão das contas, o meio por excelência para garantir o bom emprego dos dinheiros nacionais. Porém, a revisão era praticamente impossível ante a ausência de um sistema regular de contabilidade. A fim de combater tal quadro, patrocinou a edição de um regulamento e de uma instrução para os serviços do Tesouro. O Regulamento de 26 de abril de 1832 foi uma obra efetuada, nas palavras de Viçoso Jardim (1917, p. 33), "com o auxílio precioso do mais notável Contador que possuio o Thesouro - Manuel Alves Branco", que foi, entre 1830 e 1833, contador-geral, responsável por proceder à fiscalização material e legal de todos os balanços de contas do Tesouro.

Segundo o regulamento, as contadorias das tesourarias do Império, da corte e das províncias, seriam divididas em duas seções, uma de escrituração e outra de contas. Na primeira, o oficial-maior dirigiria a escrituração dos Livros Diário e Mestre e um dos escriturários efetuaria os registros no Livro Caixa. Na segunda, de revisão de contas, um escriturário incumbir-se-ia de revisar as contas de receitas e os outros quatro revisariam as contas de despe-

\footnotetext{
${ }^{2}$ Sobre Vasconcelos, ver Sousa (2015). Especificamente sobre seu desempenho liberal oposicionista, ver Alves (2013).
} 
sas. Para completar o regulamento, Alves Branco publicou as "Instruções para a Escrituração das Tesourarias do Império", que explicavam como efetuar o preenchimento dos livros contábeis e a mecânica do método das partidas dobradas, com exemplos de aplicação.

De curta duração foi a permanência deVasconcelos na pasta da Fazenda. No primeiro semestre de 1832, o Senado discutia as autorizações que a Câmara aprovara para se realizar a reforma da Constituição de 1824 e para efetivar-se a deposição de José Bonifácio do cargo de tutor do infante Pedro II. Os senadores decidiram pela restrição do escopo da reforma pretendida pelos deputados e pela manutenção de José Bonifácio. Isso precipitou uma tentativa de golpe parlamentar por parte dos regentes e, sobretudo, do ministro da Justiça, Feijó. Pretendia-se fazer a reforma constitucional a despeito das restrições do Senado (Castro, 2019). Vasconcelos implicou-se no golpe, afinal malogrado pela ação de Honório Hermeto Carneiro Leão (Sousa, 2015). Isso selou sua saída do ministério da Fazenda.

Manuel Alves Branco teve vida mais longa na Contadoria Geral, até 1833. Reeleito deputado para a terceira legislatura (1834-1837), foi eleito senador em 1837 e serviu como ministro da Fazenda entre maio e setembro daquele ano. Foi o último titular da pasta durante a Regência Una de Feijó. Em sua gestão, apresentou um projeto de lei para a criação de um tribunal de revisão de contas.

\subsection{Dois projetos e um regulamento (1837-1845)}

O projeto dispunha sobre as atribuições da instituição de controle externo da administração, essencialmente tomar contas de todos quantos manejassem dinheiros públicos, e sobre as garantias dos seus membros. Eles seriam contadores e fiscais peritos em direito. Seu número elevar-se-ia a nove, eles seriam nomeados pelo Ministério da Fazenda e não poderiam perder os cargos, exceto se por decisão judicial ou da Assembleia Geral. O presidente do tribunal, no entanto, não gozaria da mesma estabilidade, dado seu caráter temporário. As decisões da corte seriam colegiadas, por maioria dos votos (Brasil, 1887).

Em 25 de agosto de 1837, a $3^{\text {a }}$ Comissão da Fazenda da Câmara dos Deputados reconheceu a conveniência da proposta, promoveu alterações de redação e sugeriu que o ministro fosse à casa parlamentar prestar os indispensáveis esclarecimentos sobre as disposições da propositura. Um dia depois, o mesmo Bernardo Pereira de Vasconcelos que em 1830 afirmava ser nula a 
reorganização do Tesouro sem a criação de um tribunal de contas atacou o projeto de Alves Branco em duas vertentes.

$\mathrm{Na}$ primeira, administrativa, afirmou que o ministro mesmo admitia o fato de a administração fazendária, quanto à arrecadação das rendas públicas, ser irregular e defeituosa. Assim sendo, o que se esperava dele era uma proposta de reforma dos serviços de arrecadação, e não a criação de um tribunal de contas. Na segunda, política, criticou a suposta independência dos membros do tribunal, sugerindo que suas nomeações poderiam ser motivo

[...] para se lançar para fóra do tribunal da revisão algum homem da opposição, que tenha parentesco em vigésimo gráo com alguma pessoa da opposição, ou que tenha o nome de alguma pessoa da opposição; porque até os appellidos dos membros da oposição são perseguidos. (Apoiados). (Brasil, 1887, p. 397)

Tanto em 1830 como em 1837, o deputado mineiro destacava-se na oposição parlamentar, mas em polo ideológico oposto. Em 1830, liberal, opôs-se a D. Pedro I. Em 1837, tornou-se o artífice do regresso conservador. Em agosto daquele ano, fustigou o "governo de facção" do Regente Feijó, que renunciaria em 19 de setembro, abrindo espaço para a maioria regressista.

Como notou Lynch (2015), a concepção de regresso de Vasconcelos fazia dele o verdadeiro progresso, o seguro, que não lançaria o país no precipício da desordem. O autor situou o movimento regressista brasileiro da segunda metade dos anos 1830 no contexto das viradas conservadoras da época na Europa e na América. Para ele, os regressistas, tal qual os conservadores chilenos, moviam-se no espectro do liberalismo, ainda que à direita, e não na seara do reacionarismo absolutista, como os miguelistas e os carlistas em Portugal e na Espanha respectivamente. $\mathrm{Na}$ prática, isso significou uma orientação política calcada em alterações lentas e incrementais das instituições, norteadas por aquilo queVasconcelos chamou de bula das circunstâncias, isto é, as peculiaridades do país e as exigências do momento, e não por um reformismo universalista que partiria de abstrações teóricas.

Os líderes que conduziram os regressistas à formação da maioria parlamentar em 1837, Vasconcelos incluído, entendiam que a política liberal deveria ser moderada e garantida por um estado forte e centralizado. A emergência da regência de Pedro de Araújo Lima representou, segundo Needell (2009), a primeira vitória do grupo que deitou as bases do Partido Conservador. Segundo Castro (2019), no entanto, sua regência foi instável, marcada por gabinetes efềmeros. Para as instituições fazendárias e de tomada de contas, 
isso significou que reformas incrementais, ao gosto da moderação regressista, fossem efetuadas por um político liberal.

Alves Branco, que havia deixado o Ministério da Fazenda com a ascensão da maioria regressista em 1837, retornou ao mesmo ministério, em contexto de desentendimentos de Araújo Lima com as lideranças partidárias do regresso. Ele não tinha apoio para avançar seu projeto de criação de um tribunal de contas, mas promoveu melhoramentos administrativos, por meio do Decreto ${ }^{\circ}$ 41, de 20 de fevereiro de 1840, e do Regulamento de 15 de abril do mesmo ano. Possivelmente dotado do senso de oportunismo e moderação que aproximava as lideranças liberais e conservadoras nordestinas segundo Needell (2009), Alves Branco antecipou algumas linhas da abordagem saquarema para as instituições fazendárias e de tomada de contas, que se consolidaria nos anos 1850 .

O regulamento de 15 de abril de 1840 dispôs sobre os meios de execução das competências que a lei de 4 de outubro de 1831 reservara à Contadoria Geral de Revisão. O órgão foi dividido em quatro seções: Escrituração e Expediente, Dívida Pública, Balanço, Tomada e Revisão de Tomada de Contas. As duas últimas tinham relação direta com a prestação de contas e sua apresentação ao Parlamento. A justificativa foi ampliar a eficácia da execução das competências da Contadoria de Revisão, com base no aprofundamento da divisão do trabalho.

O Decreto $\mathrm{n}^{\circ} 41$, de fevereiro de 1840 , por seu turno, trouxe uma inovação de fôlego para a contabilidade pública imperial e seu sistema de prestação de contas. Ele estabeleceu, para as despesas, o regime de competência por exercícios orçamentários, em substituição ao regime de gestão ou caixa. $\mathrm{O}$ artigo $3^{\circ}$ explicou a natureza do regime orçamentário por exercícios: "são pertencentes a um exercício sómente as operações relativas aos serviços feitos, e aos direitos adquiridos ao Estado, e a seus credores dentro do anno, que dá seu nome ao exercício" (Brasil, 1863, p. 5). Isto é, deveriam ser computados como despesas não apenas os desembolsos financeiros, mas também os compromissos assumidos com os fornecedores, ainda que não pagos ao final do exercício.

O regime de competência por exercícios financeiros foi uma medida justificada em termos de verdade dos orçamentos, uma vez que impediria que compromissos assumidos em um exercício fossem levados à conta do seguinte. A verdade dos orçamentos, expressão corriqueira nos debates parlamentares, designava uma medida da aderência, ou não, das receitas e despesas 
realizadas às autorizações orçamentárias concedidas pelo Poder Legislativo e às normas contábeis e financeiras vigentes.

Alves Branco ressaltou, todavia, as limitações das reformas que executou:

Este melhoramento, Senhores, he apenas parcial, pois que como já sabeis, a minha opinião he que o verdadeiro meio de pôr a nossa contabilidade no pé, em que deve collocar-se, he a creacão de hum Tribunal de Contas, composto de membros Independentes [...]. (Brasil, 1840, p. 22)

Sem contar com o apoio da Assembleia Geral para a criação de um tribunal de contas, Alves Branco teve de se contentar com os melhoramentos parciais. Em suma, ainda que liberal, aplicou uma abordagem conservadora à reforma das instituições, isto é, manteve a revisão hierárquica das contas públicas realizada pelo Tesouro e introduziu melhorias incrementais. Em 1845, em sua última passagem à frente da pasta da Fazenda, o senador baiano tentaria uma vez mais criar uma corte de contas.

Essa foi a gestão de Alves Branco que recebeu maior atenção da historiografia, em razão da revisão das tarifas alfandegárias praticadas pelo Brasil desde os anos 1810, que, segundo Barman (1988), significou a obtenção pela nação do controle de sua política econômica. Em julho de 1845, Alves Branco ofereceu ao Parlamento mais um projeto de lei para a criação de um tribunal de contas, ao qual incumbiria "julgar anualmente as contas de todos os responsáveis por contas" e cujo primeiro trabalho, "depois de instalado, será o recopilar das leis e regulamentos atuais o que lhe parece útil para a tomada de contas" (Brasil, 1890, p. 3.432-3.433). Pediu, também, autorização parlamentar para reformar a legislação referente ao Tesouro Nacional.

Nem a criação de um tribunal de contas avançou nem a autorização lhe foi concedida. Ela seria dada, anos depois, com o seu concurso, a Joaquim José Rodrigues Torres.

\subsection{Um sistema administrativo (1850-1873)}

O período de 1850 a 1873 foi o de consolidação da abordagem institucional saquarema quanto ao sistema de contabilidade pública e tomada de contas, com o beneplácito do Imperador, que, em nenhuma das falas do trono, mencionou a verdade dos orçamentos ou sistemas de controle orçamentário, embora tenha manifestado preocupação com o equilíbrio das contas (Javari, 1993). Esse período conjugou a ação prática dos ministros da Fazenda Ro- 
drigues Torres, Torres Homem e Ângelo Moniz da Silva Ferraz com a sistematização jurídica de Paulino Soares de Sousa, o Visconde do Uruguai.

O Visconde do Uruguai discorreu sobre o caráter administrativo do Tribunal do Tesouro e acerca do contencioso administrativo a seu cargo. Considerou o sistema incompleto, porque criado a partir de vagas autorizações legislativas. Ponderou, contudo, que "mais enfezado e incompleto fosse, se sahisse, ou as bases em que devia assentar, das mãos do Corpo Legislativo" (Uruguai, 1862, p 154). Esse era o cerne da questão: o controle das contas públicas e os processos que corriam no Tribunal do Tesouro constituíam questões administrativas que não deveriam ficar sob a responsabilidade do Parlamento. Desse, bastavam as autorizações vagas.

A autorização que Alves Branco solicitou em 1845 para reformar o Tesouro Nacional, e que não lhe foi concedida, sobreveio em 1850, durante o gabinete conservador de Monte Alegre. Havia uma resolução proveniente da Câmara dos Deputados que autorizava o Poder Executivo a reformar o Tesouro, mas o ministro da Fazenda Rodrigues Torres resolveu propor diretamente ao Senado um projeto, sob a justificativa de que desejava beneficiar-se da experiência dos ex-ministros da Fazenda que compunham a câmara vitalícia. Tratava-se de um texto de 27 artigos, com escopo bem mais modesto do que a reforma que se veio a aprovar por meio do Decreto $n^{\circ} 763$, de novembro do mesmo ano (Brasil, 1978). Alves Branco, membro da comissão de Fazenda do Senado, apresentou parecer favorável à resolução da Câmara e contrário à discussão do projeto de Rodrigues Torres. A resolução tornou-se o Decreto Legislativo $n^{\circ} 563$, de 4 de julho, vago o suficiente para conceder amplitude reformadora ao Executivo.

A autorização redundou na reforma veiculada pelo Decreto $n^{\circ} 736$, de 20 de novembro de 1850, que efetuou inúmeras alterações na lei de 4 de outubro de 1831. Esta previa que o Tribunal do Tesouro fosse composto por presidente, inspetor-geral, contador-geral e procurador-fiscal. A norma de 1850 definiu uma composição com presidente, diretor-geral de rendas, diretor-geral de despesas, diretor-geral de contabilidade e procurador-fiscal. Extinguiu-se a Contadoria Geral de Revisão, que, na lei de 1831, exercia a direção superior das receitas e das despesas nacionais. O decreto de 1850 separou essas atribuições. O ordenamento das despesas ficou a cargo da Diretoria Geral de Despesa Pública; a direção, inspeção e fiscalização das rendas passou à Diretoria Geral de Rendas Públicas, enquanto a Diretoria de Geral de Contabilidade organizaria balanços e orçamentos. 
Ademais, a norma de 1850 tornou o órgão consultivo para uma série de atividades para as quais a lei de 1831 previa uma ação corretiva. Assim, por exemplo, o artigo $6^{\circ}$ da lei de 1831 permitia ao Tribunal do Tesouro demitir ou aposentar os empregados fazendários reconhecidamente desleixados ou que tivessem cometido abuso no exercício de suas funções. $\mathrm{O}$ artigo $3^{\circ}$ do decreto de 1850, por seu turno, determinou que a instituição teria voto consultivo sobre os meios de se corrigir abusos. Igualmente, a lei de 1831, em seu artigo 17, estabeleceu como prerrogativa do contador-geral a fixação do sistema de escrituração que todas as repartições fazendárias do Império deveriam seguir. $\mathrm{O}$ decreto de 1850 tornou consultivo o voto do Tribunal do Tesouro sobre a adoção do sistema de contabilidade a ser seguido nos serviços de fazenda e remeteu ao ministro da Fazenda a regulamentação da matéria. A previsão da regulamentação por parte do ministro estava presente no artigo 89 do decreto. Os avanços em matéria de contabilidade pública consolidados em normativos assinados por Alves Branco - o uso das partidas dobradas e do regime por exercícios - foram mantidos, mas mitigados, já que o ministro poderia dispensar as tesourarias de menor importância do emprego das partidas dobradas.

Ponto depois sublinhado pelo Visconde do Uruguai (1862), o decreto estabeleceu as bases do contencioso administrativo a cargo do Tribunal do Tesouro, ao dispor sobre os recursos que os cidadãos poderiam interpor das decisões do Tesouro e das tesourarias provinciais. Isso fixou claramente o caráter de corte administrativa do Tribunal do Tesouro. Esse caminho foi reforçado em 1859 pela reforma patrocinada por Francisco de Salles Torres Homem.

Polemista liberal, sob a alcunha de Timandro, Torres Homem publicou o opúsculo Libelo do Povo logo após a Revolução Praieira de 1848. Ali Torres Homem, (1981) acusou o "infeliz" governo de Pedro II de cobrir o Império de sangue e ruínas. Onze anos mais tarde, Torres Homem afastou-se do Partido Liberal e aproximou-se do imperador. Em 1859, em parceria com Rodrigues Torres, torpedeou a política de emissão de moeda do ministro Bernardo de Sousa Franco ${ }^{3}$ e, como recompensa, assumiu a pasta da Fazenda do gabinete conservador de Abaeté, por sugestão do próprio imperador (Holanda, 2010). No cargo, tomou medidas para concentrar a emissão de moeda no Banco do Brasil e reformou o Tesouro.

\footnotetext{
${ }^{3}$ Sobre o assunto sob uma perspectiva econômica, ver Villela (1999). Sob uma perspectiva política, ver Ferraz (2012).
} 
O Decreto $n^{\circ} 2.343$, de janeiro de 1859 , que veiculou a reforma, reforçou os poderes do ministro da Fazenda na administração fazendária, inclusive no Tesouro, e ressuscitou uma repartição específica para a tomada de contas. No relatório apresentado à Assembleia Geral em maio de 1859, o ministro reforçou as duas principais características do decreto: evitar subsumir as competências dos ministros da Fazenda no âmbito do Tribunal do Tesouro e reforçar o caráter de corte administrativa de contas desse órgão, possibilitando vias de recursos às suas decisões (Brasil, 1859).

Quanto às competências do ministro da Fazenda, o primeiro capítulo do decreto de 1859 definiu-o como chefe superior da administração fazendária e estabeleceu-o, dali em diante, como responsável exclusivo por algumas atribuições que o decreto de 1850 reservava ao Tribunal do Tesouro. Nesse sentido, o ministro passaria a conhecer, em primeira instância ou em grau de recurso, reclamações sobre contenciosos administrativos da Fazenda Nacional. Excetuaram-se da jurisdição ministerial os recursos que fossem interpostos quanto ao lançamento, à aplicação, à isenção, à arrecadação e à restituição de impostos, bem como os recursos que se referissem a apreensões, multas e penas corporais. Esses permaneceram sob a jurisdição do Tribunal do Tesouro.

O reforço do caráter administrativo do Tribunal do Tesouro foi encaminhado pelos artigos 27 e 28 . Segundo o ministro, o órgão tornara-se tribunal que emitia decisões das quais não havia a quem apelar. Diferentemente da legislação anterior, de 1831 e 1850, o decreto de 1859 definiu textualmente o Tribunal do Tesouro como corte administrativa de contas e atribuiu às decisões do órgão, assim como às do ministro de Estado, a força de sentença dos tribunais de justiça. $\mathrm{O}$ ministro poderia devolver ao órgão as decisões que considerasse incompetentes e ilegais. Essa faculdade estendia-se, também, ao Conselho de Estado, que poderia anular as decisões exaradas pelo Tribunal do Tesouro e pelos chefes de repartições fiscais em matérias contenciosas, a requerimento da parte interessada, nos casos de incompetência, excesso de poder e violação da lei. No caso das tomadas de contas, dois recursos foram previstos pelo decreto: de revisão ao próprio Tribunal do Tesouro e de revista ao imperador em Conselho de Estado.

Para Torres Homem, a inserção do Conselho de Estado como órgão máximo de revisão supria uma lacuna da legislação, uma vez que o Tribunal do Tesouro era órgão administrativo e o imperador, em Conselho de Estado, era "o superior legítimo de todas as Autoridades e Tribunaes administrativos" (Brasil, 1859, p. 25). 
O Decreto $\mathrm{n}^{\circ} 2.548$, de março de 1860 , completou a obra reformadora de Torres Homem. Ele dispôs sobre o regulamento de tomada de contas por parte do Tesouro e foi editado por seu sucessor, Ângelo Moniz da Silva Ferraz, o Barão de Uruguaiana. Seu artigo $1^{\circ}$ reforçou a identidade conferida pelos saquaremas ao Tribunal do Tesouro: "tribunal administrativo para a tomada de contas". As competências do órgão, quanto à tomada de contas, foram esmiuçadas, com base no disposto pelo decreto de 1859. Estabeleceram-se, ainda, os procedimentos necessários a serem seguidos pelos interessados em interpor recursos previstos pelo Decreto $n^{\circ} 2.343$, de 1859.

Juntos, os Decretos n ${ }^{\circ} 736$, de 1850; $n^{\circ} 2.343$, de 1859; e n 2.548 , de 1860 , conformaram as bases do mais bem organizado sistema de julgamento administrativo do Império segundo Lopes (2010). À exceção dele, o Visconde do Uruguai (1862) considerava caótico o contencioso administrativo dos ministérios. Com efeito, a Seção de Fazenda do Conselho do Estado era frequentemente acionada sobre as decisões do Tribunal do Tesouro (Melo, 2018). Quanto às tomadas de contas, pelo menos uma consulta foi efetuada já em 1860 , a de $n^{\circ} 593$, que dizia respeito a uma decisão do Tesouro, afinal não revertida pelo Conselho, sobre a devolução de vencimentos considerados ilegalmente percebidos (Brasil, 1871).

As reformas de Rodrigues Torres, Torres Homem e de Silva Ferraz assentaram as instituições de contabilidade pública e tomada de contas do Império segundo a ótica saquarema e receberam sistematização doutrinal do Visconde do Uruguai:

Assim os desvios administrativos, a offensa a direitos em questões administrativas não tem correctivo efficaz, suficiente, e real, na responsabilidade dos ministros [...] O único efficaz que póde ter encontra-se na separação pratica possível, entre o que he político e administrativo. Essa separação não consiste nem poderia consistir em tirar a administração do Poder Executivo. Fôra o mesmo que suprimi-lo. Não póde consistir também em sujeita-lo a outro Poder, ou em fazer depender deste a solução das duvidas que por ventura se suscitem sobre os actos administrativos do executivo, porque fora isto anulla-lo, e abrir larga fonte de desordem e de conflitos. (Uruguai, 1862, p. 21-22)

O sentido da direção saquarema está claro no excerto. Havia que se preservar o sistema de repartição de poderes da Constituição de 1824, reforçando-se o Poder Executivo, sem sujeitá-lo a outro poder, leia-se o Legislativo. Esse era o princípio da ordem. E prossegue o ilustre membro da trindade 
saquarema: "qual a maioria parlamentar que, por questões dessas, se prestará a sacrificar um ministério que sustenta, a dar razão aos seus adversários, e lugar a que suba a opposição?” (Uruguai, 1862, p. 21). Não satisfeito em sublinhar que o Poder Legislativo não puniria os abusos cometidos por ministérios apoiados pela maioria, apontou, ainda, a inépcia técnica do corpo parlamentar: "as câmaras são pouco próprias para entrarem em minuciosos desenvolvimentos administrativos” (Uruguai, 1862, p. 155). Foi essa concepção, transformada em direção política, que inviabilizou a criação de um tribunal de contas, auxiliar do Poder Legislativo, e a sistematização da miríade de regulamentos de contabilidade pública. Gestada desde o regresso conservador, ela foi consolidada institucionalmente nos anos 1850-1860.

A construção institucional saquarema quanto à fiscalização das contas da administração pública coadunou-se com as diretrizes da hegemonia saquarema. Essa, nos termos de Mattos (1987), representou tanto uma direção política e intelectual como uma hierarquia entre saquaremas e luzias, por meio da qual os primeiros não necessitavam chefiar gabinetes para conferir os contornos e rotinizar o funcionamento das instituições do Império. Alonso (2002) acentuou, ainda, que os liberais jamais conseguiram alterar a essência das instituições que deitaram as bases da hegemonia saquarema, dentre elas a estrutura político-administrativa centralizada e a concentração de poderes no Conselho de Estado e no Senado. Ora, a circunscrição da tomada de contas no âmbito do Poder Executivo, com revisão possível pelo Moderador, representou o cerne da direção saquarema em termos de prestação de contas públicas e não foi alterada pelos liberais posteriormente. Modificações modestas se seguiram. Duas delas em particular dão a dimensão da direção saquarema aplicada ao sistema de contabilidade pública.

A primeira foi efetuada por Zacarias de Góes e Vasconcelos em 1868. Ele editou o Decreto ${ }^{\circ} 4.153$, de 6 de abril, que revogou partes do Decreto $\mathrm{n}^{\circ} 736$, de 20 de novembro de 1850 . $\mathrm{O}$ artigo $6^{\circ}$ suprimiu a escrituração a limpo do livro de receitas e despesas classificadas na Diretoria Geral de Contabilidade e a escrituração dos livros de contas correntes. Medida estrutural, a escrituração central do Império foi extinta. Ademais, aboliu-se a exigência de conhecimento das partidas dobradas para a nomeação de praticantes do Tesouro e das tesourarias. Sequer para a promoção dos praticantes à posição de amanuenses seria exigida a proficiência no método.

O tratamento conferido à questão pelo último gabinete Zacarias oferece indícios sobre como as diretrizes saquaremas prevaleceram mesmo 
quando não eram eles a chefiar gabinetes. Zacarias reformou o Tesouro para simplificar práticas contábeis e reduzir despesas, não para aumentar a eficácia dos controles contábeis e os subsídios à disposição do Parlamento para a responsabilização dos agentes públicos. A redução de despesas, para ele, se deu sem malefícios aos serviços, que puderam ser organizados de uma maneira mais modesta, com pessoal menos numeroso (Brasil, 1868).

A reorganização mais modesta a que se referiu Zacarias, no entanto, trabalhava contra as máximas sagradas declaradas por seu Partido Progressista:"a responsabilidade dos ministros de estado pelos atos do Poder Moderador; a verdade do orçamento" (Brasiliense, 1878, p. 17). Ora, as medidas tomadas pelo político que se declarava a favor de freios que impedissem os abusos por parte do poder Executivo e do Moderador (Góes eVasconcelos, 1862) esmaeceram os instrumentos de controle de desvios orçamentários e, assim, a obtenção da verdade dos orçamentos.

Os termos da justificativa de Zacarias - simplificação de expedientes e redução de despesas - foram retomados pelo Visconde do Rio Branco. Seu gabinete reformista realizou parte do programa liberal anterior ao manifesto do Partido Liberal de 1869, com medidas que alcançaram a guarda nacional, ampliaram o habeas-corpus e reformaram parcialmente o Estado (Alonso, 2002). Essas últimas, no que dizia respeito à fiscalização das contas da administração pública, no entanto, não incluíram a bandeira liberal de criação de um tribunal de contas. Pelo contrário, Rio Branco promoveu sua própria simplificação de expedientes contábeis e de controle, por meio do Decreto $\mathrm{n}^{\circ} 5.245$, de 5 de abril de 1873. Por um lado, elevou os vencimentos dos servidores do Tesouro; por outro, promoveu extinções: de cargos, da escrituração de Livros Diários e da revisão de contas perante a Fazenda Pública, salvo nos casos em que a Diretoria de Tomada de Contas julgasse indispensável ou que envolvessem importâncias significativas.

Com o gabinete Rio Branco, terminou o ciclo iniciado em 1850, de reformas incrementais do Tesouro, que fortaleceram seu caráter administrativo, simplificaram práticas de controle e interditaram a emergência de um órgão de controle externo auxiliar do Poder Legislativo. Dali em diante, a intervenção direta da coroa nos assuntos relacionados ao trabalho escravo esmaeceria a direção saquarema (Needell, 2006) e enfraqueceria a sustentação ao próprio regime (Carvalho, 2010). Quanto às questões referentes à contabilidade pública e à tomada de contas, houve intensificação das demandas pela criação de um tribunal de contas. 


\subsection{O Proteu do abuso e a verdade dos orçamentos no final do Império}

Em 27 de julho de 1883, a coluna "Balanços" do Jornal do Commercio efetuou uma avaliação sobre a legislação que regia os balanços do Império. Afirmou não desconhecer as dificuldades de se lidar com a matéria orçamentária, dado que o melhor orçamento não era senão uma previsão. Contudo, asseverou que o Proteu do abuso escondia-se na falta de clareza dos orçamentos imperiais.

O diário carioca julgava inaceitável um balanço levar dois anos para ser concluído e submetido ao Poder Legislativo.A demora retirava dos parlamentares a oportunidade de julgamento dos responsáveis pelas contas, pois muitos deles já não ocupavam mais os cargos quando essas aportavam no Parlamento. "Eis matéria mui digna de providência: contas antiquadas não desafião inspecção eficaz senão em tribunais especiaes onde homens de officio tem assento permanente" (Jornal do Commercio, 1883, p. 1). O jornal não desenvolveu a ideia do tribunal especial para inspecionar as contas, mas pugnou pela simplificação da apresentação delas.

A demanda por um tribunal de contas, todavia, já havia sido efetuada pelo ministro da Fazenda, Gaspar Silveira Martins. Membro do gabinete liberal de Sinimbu, considerava inconveniente um sistema no qual os serventuários da Diretoria de Tomada de Contas do Tesouro nada podiam contra o ministro ordenador da despesa, de quem dependiam e a quem se subordinavam. Ele denunciou os orçamentos feitos ao sabor da tesoura dos ministros, que modificavam rubricas orçamentárias à revelia dos parlamentares, e chamou os balanços levados ao conhecimento do Poder Legislativo de fraudulentos. "Seria, pois, de necessidade imprescindível para a regeneração das finanças crear um Tribunal de Contas" (Brasil, 1878b, p. 20). A regeneração implicaria restituir a verdade dos orçamentos aos olhos do Parlamento.

Seu sucessor, o Visconde de Ouro Preto, asseverou ser urgentíssima a necessidade de criação de um tribunal de contas, "que examinando em face das autorizações legislativas as despezas ordenadas pelos Ministérios de Estado, forneça ao Parlamento base segura para exercer a fiscalização" (Brasil, 1879 , p. 32). Seu modelo era a Cour de Comptes francesa. Chegou-se, na comissão da Câmara dos Deputados que discutia os orçamentos para 1879-1880 e 1880-1881, a se propor emenda autorizando o Poder Executivo a criar a corte de contas (Jornal do Commercio, 1879, p. 2).A lei orçamentária finalmente aprovada, $\mathrm{n}^{\circ} 2.940$, de outubro de 1879, no entanto, não incorporou nem a emenda da comissão da Câmara nem o clamor do ministro. 
Nos sete anos de gabinetes liberais entre 1878 e 1885, além de Silveira Martins e do Visconde de Ouro Preto, Lafayette Rodrigues Pereira tornou às questões, interligadas, do tribunal de contas e das normas de contabilidade pública. Ele considerava

[...] da maior urgência organisar, entre nós, um systema uniforme de contabilidade pública, que, fornecendo provas irrecusaveis da applicaçao dos rendimentos do Estado e da exatidão das contas ministeriaes, habilite o Poder Legislativo para apreciar, à luz da evidencia e no tempo conveniente, a gerencia financeira e a responsabilidade do Governo, cessando o adiamento indefinido da fiscalisação parlamentar. (Brasil, 1884, p. 66)

O Conselheiro Lafayette fora signatário do Manifesto Republicano de 1870, que fulminara o princípio dinástico em geral e o Poder Moderador em particular, sob a justificativa de que ensejavam governos infensos à responsabilização, já que poderiam dissolver a Câmara dos Deputados (Brasiliense, 1878). Em 1884, o ministro, ao retomar a questão da responsabilidade dos governos em face do Parlamento, tomou uma medida concreta. Criou uma comissão, presidida pelo Barão de Paranapiacaba, procurador fiscal do Tesouro, para reduzir o emaranhado de normas contábeis a um "complexo de prescrições" e delinear "a maneira de organizar o Tribunal de Contas" (Brasil, 1884, p. 67).

O ministro informou que a Comissão de Consolidação da Contabilidade Pública trabalhava no começo de 1884 e, brevemente, daria contas de sua tarefa, que seria submetida, no que coubesse, à aprovação do Parlamento. Negligenciada pela historiografia, há registros do seu funcionamento até 1886, quando, em 7 de junho, o jornal Diário de Notícias (1886) informou que o contador Miguel Arcanjo assumira sua presidência.Todavia, as normas de contabilidade pública não foram consolidadas, tampouco se delineou a criação de uma corte de contas.

O último ministro da Fazenda a explicitar a necessidade de codificar as normas de contabilidade pública e criar um tribunal de contas foi o primeiro ministro conservador a fazê-lo: João Alfredo Correa de Oliveira. Para ele, urgia terminar o trabalho de consolidação da contabilidade administrativa e retirar da administração um serviço que até então lhe incumbia, a fiscalização do uso de dinheiros públicos. Impunha-se, pois, criar um tribunal de contas, "que, conhecendo de toda a contabilidade do Estado, possua meios para assegurar às Câmaras e à Nação que os balanços demonstram fiel e perfeitamente 
o movimento dos dinheiros públicos" (Brasil, 1889, p. 25).A adesão do último conservador que chefiou um gabinete a uma demanda que seu partido historicamente refutou e que era defendida debalde por liberais tardara.

Isso se deu em maio de 1889. Em junho do mesmo ano, o liberal Visconde de Ouro Preto, que acumulava o ministério da Fazenda com a presidência do Conselho de Ministros, conclamou o Parlamento a se fiar na plasticidade reformista do regime, para ampliar a autonomia das províncias, estabelecer o equilíbrio das receitas com as despesas públicas ordinárias e a temporariedade do Senado, entre outras medidas (Brasil, 1889). Essas reformas não ocorreram, assim como não foram efetuadas a consolidação das normas de contabilidade pública e a criação do tribunal de contas. Não houve muito mais tempo para o Império.

\section{Conclusão}

A esta altura, a evidência apresentada permite propor uma explicação para o fato de a criação de um tribunal de contas e a sistematização das normas de contabilidade pública não terem sido efetuadas no Império, embora discutidas desde 1826.

Sustenta-se aqui que tais desenvolvimentos institucionais não ocorreram porque os saquaremas estenderam sua abordagem administrativa às questões da tomada de contas e da contabilidade pública, de modo a afastá-las do âmbito da discussão sobre os checks and balances da monarquia constitucional. Não prosperou a proposta liberal de controle das contas do Poder Executivo pelo Poder Legislativo com o concurso de um tribunal de contas composto por membros independentes com relação ao governo.A execução e a tomada de contas de responsáveis pelo manejo de recursos públicos foram mantidas sob o Tribunal do Tesouro, órgão do Poder Executivo, circunscrito ao campo administrativo e cujas decisões poderiam ser revistas pelo imperador, por meio da Seção de Fazenda do Conselho de Estado.

A direção saquarema impediu que eventuais abusos cometidos pelos agentes do Poder Executivo imperial fossem expostos ao escrutínio dos parlamentares a partir dos subsídios fornecidos por uma instituição dedicada exclusivamente à análise das suas contas. Os liberais desejavam, discursivamente, regras claras de contabilidade pública e o controle de contas independente do Poder Executivo, a fim de restituir a verdade aos orçamentos e instituir mecanismos de responsabilização, algo que fortaleceria o poder do Parlamento na ordem constitucional monárquica. Eles foram derrotados porque sua demanda 
colidia com os princípios garantidores da ordem para os saquaremas: o Poder Executivo forte e as prerrogativas imperiais intactas. $\mathrm{Na}$ prática, quando na chefia de gabinetes, não desafiaram a direção saquarema quanto a esses assuntos.

A hegemonia saquarema refletida no sistema de contabilidade pública consolidou nas mãos dos ministros e do imperador em Conselho de Estado a direção das tomadas de contas, das normas de contabilidade pública e do contencioso administrativo-fazendário. Essas matérias foram definidas pelos conservadores como administrativas e, portanto, fora das competências legais e técnicas do Parlamento.

Em suma, a codificação das normas de contabilidade pública e a criação e um órgão de controle externo não foram efetuadas no regime imperial porque concorreriam para viabilizar o programa daqueles que desejavam que o imperador se circunscrevesse a reinar e que a administração dirigida pelos governos fosse responsável perante o Parlamento. A isso resistiram os saquaremas por quase todo o período. Somente o último gabinete conservador propôs claramente criar uma corte de contas e sistematizar as regras de contabilidade pública. Era tarde. A resolução da questão da escravidão minara o apoio político ao próprio Império.

\section{Referências}

AIDAR, B. A reforma do Tesouro Nacional e os liberais moderados. In: RIBEIRO, G. S.; CAMPOS, A. P. História sobre o Brasil no Oitocentos. São Paulo: Alameda, p. 13-36, 2016.

ALONSO, Â. Ideias em movimento: a geração de 1870 na crise do Brasil Império. São Paulo: Paz e Terra, 2002.

ALVES,J.V.C. Ascensão e queda do gabinete de 20 de novembro de 1827 (1827-1829). São Paulo: Cultura Acadêmica, 2013. (Coleção PROPG Digital - UNESP). ISBN 9788579834806. Disponível em: <http://hdl.handle. net/11449/109299>. Acesso em: 20 jan. de 2020 .

BARMAN, R. J. Brazil: the forging of a Nation (1758-1852). Stanford: Stanford University Press, 1988.

BRASIL. Câmara dos Deputados. Annaes do Parlamento Brazileiro. C Câmara 
dos Srs. Deputados. Primeiro Anno da Segunda Legislatura. Sessão de 1830. Rio de Janeiro: Typographia de H.J. Pinto, 1878a. Disponível em: $<$ http:// memoria.bn.br>.Acesso em: 10 fev. 2020.

BRASIL. Câmara dos Deputados. Annaes do Parlamento Brazileiro. C Câmara dos Srs. Deputados. Quarto Anno da Terceira Legislatura. Sessão de 1837. Rio de Janeiro: Typographia de Viúva Pinto \& Filho, 1887. Disponível em: <file:///C:/Users/User/AppData/Local/Temp/anais_camara_1837_vol2. pdf>. Acesso em: 10 fev. 2020.

BRASIL. Câmara dos Deputados. Coleção de Anais da Câmara dos Deputados. Sessão de 11 de junho de 1889. Disponível em: <https://imagem.camara. leg.br/dc_20b.asp?selCodColecaoCsv=A\&Datain=11/6/1889\#/>. Acesso em: 24 abr. 2019.

BRASIL. Colleç̧ão das Leis do Império do Brazil de 1840. Rio de Janeiro:Typographia Nacional, 1863. (Tomo II, Parte II).

BRASIL. Imperiaes resoluções do Conselho de Estado na secção de Fazenda desde o anno que começou a fincuccionar o mesmo Conselho até o presente: annos de 1856 a 1860. Rio de Janeiro:Typographia Nacional, 1871. (Volume IV).

BRASIL. Ministério da Fazenda (Affonso Celso de Assis Figueiredo). Proposta e relatório apresentado à Assembleia Geral Legislativa, na segunda sessão da décima sétima legislatura, pelo Ministro e Secretário de Estado dos Negócios da Fazenda Affonso Celso de Assis Figueiredo. Rio de Janeiro:Typografia Nacional, 1879.

BRASIL. Ministério da Fazenda (Bernardo Pereira de Vasconcelos). Relatório apresentado à Câmara dos Senhores Deputados pelo Ministro e Secretário d'Estado dos Negócios da Fazenda Bernardo Pereira de Vasconcelos na sessão de 1832. Rio de Janeiro: Typografia Nacional, 1832.

BRASIL. Ministério da Fazenda (Francisco de Salles Torres Homem). Proposta e relatório apresentado à Assembleia Geral Legislativa, na terceira sessão da décima legislatura. Rio de Janeiro:Typografia Nacional, 1859.

BRASIL. Ministério da Fazenda (Gaspar Silveira Martins). Proposta e relatório 
apresentado à Assembleia Geral Legislativa, na primeira sessão da décima sétima legislatura, pelo Ministro e Secretário de Estado dos Negócios da Fazenda Gaspar Silveira Martins. Rio de Janeiro:Typografia Nacional, 1878b.

BRASIL. Ministério da Fazenda (João Alfredo Corrêa de Oliveira). Proposta e relatório apresentados à Assembleia Geral Legislativa, na quarta sessão da vigésima legislatura, pelo Ministro e Secretário de Estado dos Negócios da Fazenda João Alfredo Corrêa de Oliveira. Rio de Janeiro: Imprensa Nacional, 1889.

BRASIL. Ministério da Fazenda (Lafayette Rodrigues Pereira). Proposta e relatório apresentado à Assembleia Geral Legislativa, na quarta sessão da décima oitava legislatura, pelo Ministro e Secretário de Estado dos Negócios da Fazenda Lafayette Rodrigues Pereira. Rio de Janeiro:Typografia Nacional, 1884.

BRASIL. Ministério da Fazenda (Manoel Alves Branco). Proposta e relatório apresentado à Assembleia Geral Legislativa, na sessão ordinária de 1840, pelo Ministro e Secretário de Estado dos Negócios da Fazenda Bernardo Manoel Alves Branco. Rio de Janeiro:Typografia Nacional, 1840.

BRASIL. Ministério da Fazenda (Zacarias de Góes e Vasconcellos). Proposta e relatório apresentado à Assembleia Geral Legislativa, na segunda sessão da décima terceira legislatura, pelo Ministro e Secretário de Estado dos Negócios da Fazenda Zacarias de Góes e Vasconcellos. Rio de Janeiro:Typografia Nacional, 1868.

BRASIL. Senado do Império do Brazil. Annaes do Senado do Império do Brazil. Primeira sessão da primeira legislatura. Anno de 1826. Rio de Janeiro:Typographia Nacional, 1878c. (Tomo Segundo).

BRASIL. Senado do Império do Brazil. Annaes do Senado do Império do Brazil. Primeira sessão da primeira legislatura. Anno de 1826. Rio de Janeiro:Typographia Nacional, 1878d. (Tomo Terceiro).

BRASIL. Senado Federal. Anais do Império do Brasil. Sessão Legislativa Ordinária $-8^{a}$ Legislatura. Sessões de junho de 1850. Brasília: Senado Federal. Subsecretaria de Anais, 1978.

BRASILIENSE, A. O programa dos partidos e o $2^{\circ}$ Império. São Paulo: Typografia de Jorge Steckler, 1878. 
CARVALHO, J. M. de. A construção da ordem: a elite política imperial. Teatro das sombras: a política imperial. Rio de Janeiro: Civilização Brasileira, 2010.

CASTRO, P. P. A experiência republicana, 1831-1840. In: HOLANDA, S. B. de (Org.). História geral da civilização brasileira. Tomo III: o Brasil monárquico.V. 4: dispersão e unidade. Rio de Janeiro: Bertrand Brasil, p. 19-84, 2019.

D'ASSUNÇÃO BARROS,J. Os Annales e a história-problema - considerações sobre a importância da noção de "história-problema" para a identidade da Escola dos Annales. Revista História: Debates ETendências, v. 12, n. 2, p. 305-325, 2013. Disponível em: <https://doi.org/10.5335/hdtv.12n.2.3073>. Acesso em: 27 out. 2021.

DEVEZA, G. Política tributária no período imperial. In: Sérgio Buarque de Holanda. (Org.) História Geral da civilização brasileira: o Brasil monárquico - Declínio e queda do Império. Tomo II, v. 6. Rio de Janeiro: Bertrand Brasil, 2016.

FEBVRE, L. Combates pela História. Lisboa: Editorial Presença, 1989.

FERRAZ, S. E. O Império revisitado: instabilidade ministerial, Câmara dos Deputados e Poder Moderador (1840-1889). São Paulo: USP, 2012 (Tese de Doutorado em Ciência Política da USP).

GÓES E VASCONCELOS, Z. de. Da natureza e limites do Poder Moderador. Rio de Janeiro:Typographia Universal de Laemmert, 1862.

HALL, P. A.; TAYLOR, R. C. Rosemary. As três versões do neo-institucionalismo. Lua Nova, n. 58, p. 193-223, 2003.

HOLANDA, S. B. de. Capítulos de história do Império: manuscritos. São Paulo: Companhia das Letras, 2010.

JARDIM,V. A contabilidade pública do Brasil. Rio de Janeiro: Jacintho Ribeiro dos Santos Editor, 1917.

JAVARI, B. de (Org.). Império brasileiro: falas do trono, desde o ano de 1823 até o ano de 1889, acompanhadas dos respectivos votos de graça da Câmara 
Temporária e de diferentes informações e esclarecimentos sobre todas as sessões extraordinárias, adiamentos, dissoluções, sessões secretas e fusões com um quadro das épocas e motivos que deram lugar à reunião das duas câmaras e competente histórico, coligidas na Secretaria da Câmara dos Deputados. Rio de Janeiro: Editora Itatiaia, 1993.

JORNAL Diário de Notícias. Declarou-se ao contador do Thesouro Nacional, Miguel Archanjo Galvão, que deve assumir a presidência da Comissão nomeada em 28 de janeiro e 1884 para consolidar a legislação sobre a contabilidade pública. Rio de Janeiro, 7 de junho de 1886, p. 2. Disponível em: <http://memoria.bn. br/>. Acesso em: 25 nov. 2019.

JORNAL do Commercio. Balanços. Rio de Janeiro, 27 de julho de 1883, p. 1. Disponível em: <http://memoria.bn.br>.Acesso em: 25 nov. 2019.

JORNAL do Commercio. Câmara dos Deputados. Acta de 29 de março de 1879. Rio de Janeiro, 30 de março de 1879. Disponível em: <http://memoria.bn. br>.Acesso em: 25 nov. 2019.

JORNAL do Commercio. Distribuição de créditos. Rio de Janeiro, 18 de janeiro de 1883, p. 1. Disponível em: <http://memoria.bn.br>. Acesso em: 14 nov. 2020.

LOPES, J. R. de L. O oráculo de Delfos: o Conselho de Estado no Brasil-Império. São Paulo: Saraiva, 2010.

LOPES, L. S.; HANLEY, A. G. Alice no País da contabilidade: a aventura de duas historiadoras econômicas em registros contábeis do século XIX. Revista Contabilidade e Finanças, v. 25, n. spe, p. 355-363, dez. 2014. Disponível em: $<$ http://www.scielo.br/scielo.php?script=sci_arttext\&pid=S1519$-70772014000500355 \& \operatorname{lng}=\mathrm{en} \& \mathrm{nrm}=$ iso $>$. Acesso em: $27 \mathrm{abr} .2021$.

LYNCH, C. E. C. Modulando o tempo histórico: Bernardo Pereira de Vasconcelos e conceito de "regresso" no debate parlamentar brasileiro (18381840). Almanack, n. 10, p. 314-334, ago. 2015. Disponível em <http://www. scielo.br/scielo.php?script=sci_arttext\&pid=S2236-46332015000200314\&ln $\mathrm{g}=$ en\&nrm $=$ iso $>$. Acesso em: 25 jan. 2020. 
MATTOS, I. R. de. O tempo saquarema. São Paulo: Hucitec, Brasília: INL, 1987.

MELO, J. C. de. Consultas da Seção de Fazenda do Conselho de Estado (18421889): Tendências e Perfil de sua Atividade. Porto Alegre, 2018. Disponível em: <http://www.eeh2018.anpuh-rs.org.br/site/anaiscomplementares $>$. Acesso em: 20 abr. 2014.

NEEDELL, J. The party of order: the conservatives, the State, and slavery in the brazilian monarchy, 1831-1871. Stanford: Stanford University Press, 2006.

NEEDELL, J. D. Formação dos partidos brasileiros: questões de ideologia, rótulos partidários, lideranças e prática política, 1831-1888. Almanack Braziliense, n. 10, 2009, p. 54-63. Disponível em https: <//www.revistas.usp.br/ alb/article/view/11719>. Acesso em: 10 abr. 2021.

NORTH, D. C. Institutions, institutional change and economic performance. Cambridge: Cambridge University Press, 2003.

RAMOS, E. S. Centralização e privilégio: instituições e fiscalidade na formação do Estado brasileiro (1808-1836). São Paulo: USP, 2018 (Dissertação de Mestrado da USP).

RODRIGUES, L. L.; CRAIG, R. J.; SCHMIDT, P.; SANTOS, J. L. Documenting, monetising and taxing Brazilian slaves in the eighteenth and nineteenth centuries. Accounting History Review, v. 25, n. 1, p. 43-67, 2015. Disponível em: <http://dx.doi.org/10.1080/21552851.2014.946935>.Acesso em: 27 set. 2021 .

SILVA, A. F. da. A contabilidade brasileira no século XIX: leis, ensino e literatura. São Paulo: PUC-SP, 2005 (Dissertação de Mestrado em Ciências Contábeis e Financeiras da PUC-SP.

SOUSA, O.T. de. História dos fundadores do Império do Brasil. Volume III. Bernardo Pereira de Vasconcelos. Brasília: Senado Federal, Conselho Editorial, 2015. 
STRATEN-PONTHOZ, A. van der. Le budget du Brésil ou recherches sur les ressources de cet empire dans leurs rapports avec les intérêts européens du commerce et de l'émigration. Paris: Librairie d'Amyot, 1854.

TORRES HOMEM, F. de S. O libelo do povo. RCP, v. 24, n. 3, set. /dez., p. 147-184, 1981.

URUGUAI, V. do. Ensaio sobre o direito administrativo. Rio de Janeiro: Typographia Nacional, 1862.

VELLOZO,J. C. de O. Constituição e responsabilidade no Império do Brasil: embates parlamentares sobre a responsabilização de ministros, magistrados e empregados públicos em geral (1826-1832). São Paulo: USP, 2017 (Tese de Doutorado em História Social da USP).

VILLELA, A. A. The political economy of money and banking in Imperial Brazil, 1850-1870. Londres: LSE, 1999 (Tese de Doutorado em Filosofia da London School of Economics and Political Science.

VIOTTI DA COSTA, E. Da monarquia à República: momentos decisivos. São Paulo: Editora Unesp, 2007. 